\title{
Corrosion of Natural Glasses in Seawater
}

\section{Chapter 7.3}

Encyclopedia of Glass Science, Technology, History, and Culture, Volume II, First Edition. Pascal Richet. (C) 2021 The American Ceramic Society. Published 2021 by John Wiley \& Sons, Inc.

https://doi.org/10.1002/9781118801017.ch7.3

\section{Roland Hellmann}

ISTerre, CNRS, Université Grenoble Alpes, CS 40700, F-38058 Grenoble Cedex 9, France

\section{Reviewers}

A.-M. Karpoff, École et Observatoire des Sciences de la Terre, Strasbourg, France

O. Majerus, École Nationale Supérieure de Chimie de Paris, Paris, France

\section{Abstract}

Chemical alteration of basalt glasses in seawater ranks as one of the most important global Earth processes, playing a significant role in the terrestrial carbon cycle, the chemical composition of the oceans, and the cycling of major, minor and trace elements between the crust and the mantle. This chapter examines abiotic and biotic processes that drive seafloor alteration of basaltic glasses. Biotic alteration depends on specific metabolic processes that supply energy to microorganisms, and at the same time, serve to breakdown the glass structure. Several representative studies illustrate current models of abiotic and biotic basalt glass dissolution. In most cases, the predominant alteration product is palagonite, a secondary surficial phase that grows at the expense of the glass. Its physical and chemical properties indicate how it forms, which in turn is linked to the glass corrosion mechanism. Each study is discussed in light of the two currently accepted corrosion mechanisms: the cation-depleted leached layer model and the coupled interfacial dissolution-reprecipitation (CIDR) model. 


\section{Introduction}

The chemical alteration of natural volcanic glasses plays a major role in controlling seawater chemistry [1] and aqueous $\mathrm{CO}_{2}$ uptake during dissolution [2]. Of particular importance is the chemical alteration of basalt (Ch. 7.2) that makes up much of the oceanic crust. Rapid quenching of magma by seawater, in particular at mid-ocean ridges (MOR, the long submarine volcanic chains formed by upwelling magma at divergent plate boundaries), leads to the production of large volumes of basaltic glass. In fact, basalt glass comprises $20 \%$ of the extrusive layer of oceanic crust in the Atlantic [1].

Interaction with seawater results in chemical alteration of both basalt rock and glass, the latter being by far the most reactive phase because of its metastability. Given the volumetric importance and high reactivity of basaltic glass, its chemical alteration by seawater represents a key process in controlling the composition of oceans, and can even be considered as a proxy for chemical weathering of oceanic crust [1]. When altered oceanic crust is brought down into the mantle by subduction, the cycling of elements, including halogens and noble gases [3], is therefore in large part also controlled by seawater-basalt interactions. In addition, these interactions consume aqueous $\mathrm{CO}_{2}[2]$, thereby making this process an important part of the global carbon cycle. Since basalt is rich in calcium and magnesium oxides, reaction with $\mathrm{CO}_{2}$-rich solutions can lead to extensive formation of $\mathrm{Ca}$ and $\mathrm{Mg}$-carbonates, which represents permanent geological sequestration of carbon [4-6]. Basalt glass alteration is also important for industrial applications, in particular as an analog process for nuclear glass corrosion over geological time scales [7].

In this chapter, the metabolic processes of microorganisms living in seafloor basalt environments are presented, many of which are related to reactions that lead to biologically mediated basalt glass alteration. A critical analysis of current models of biotic and abiotic alteration is then made in terms of the preferential cation leaching and coupled interfacial dissolution-reprecipitation (CIDR) mechanisms (Ch. 5.12). The first theory postulates that certain labile cations are preferentially released from the glass structure and replaced by hydronium ions $\left(\mathrm{H}_{3} \mathrm{O}^{+}\right)$from the surrounding fluid. The overall process, controlled by interdiffusion, results in the formation of a cation-leached, silicarich surface layer. According to the second theory, these surface layers form by the contemporaneous coupling of congruent glass dissolution and reprecipitation of a hydrated silica 
surface layer. This is an interfacial chemical process that occurs within a thin fluid film of ordered water molecules bound to the pristine glass surface. In the first theory, the leached layer is characterized by broad sigmoidal cation depth profiles, whereas a very sharp chemical and structural interface separates the silica layer from the glass in the second theory.

\section{From basalt glasss to palagonite}

Bulk basalt glasses formed at mid-ocean ridges generally have the same composition as basalt rock, being mainly composed of $\mathrm{SiO}_{2}, \mathrm{Al}_{2} \mathrm{O}_{3}, \mathrm{CaO}, \mathrm{MgO}, \mathrm{FeO}$ [8]. Another basalt glass type, called interstitial, is primarily composed of just $\mathrm{SiO}_{2}$ and $\mathrm{Al}_{2} \mathrm{O}_{3}$. It constitutes the matrix of crystalline phases within pillow basalts, massive flows, and dikes [8].

The first step in the chemical alteration of basalt glass in seawater at low temperatures generally results in the formation of palagonite - German Palagonit, from Palagonia, Sicily [9]. This phase is akin to a gel and appears as a brown to yellow colored rind forming a distinct surficial layer on the pristine glass $[10,11]$. Its chemical and structural complexity has been investigated by transmission electron microscopy (TEM) and nano-secondary ion mass spectrometry (nanoSIMS) [12]. Palagonite has sometimes been specifically characterized as a hydrated, cation-depleted altered glass layer, but more often is simply considered as a surface alteration product originating from the hydration and oxidation of fresh glass, which results in a porous mix of amorphous, poorly crystalline, and crystalline authigenic (i.e., formed in situ) phases. In contrast, interstitial glass alteration may not involve palagonite formation, but rather direct formation of clays [8]. The presence of palagonite between fresh glass and authigenic phases has not always been discerned, but in many cases can be attributed to insufficient analytical resolution.

Secondary authigenic minerals, such as phyllosilicates, zeolites or Fe, Mn-oxyhydroxides, may form on the palagonite surface either from a surrounding oversaturated bulk solution, or in specific cases, through in-situ transformation of the palagonite itself. In environments with elevated temperatures (up to $\sim 400{ }^{\circ} \mathrm{C}$ ), such as found at hydrothermal seafloor vents, a different suite of secondary phases will form. In general, precipitation of authigenic minerals within pore spaces may hinder access of seawater to the fresh glass interface, thus passivating the alteration reaction [13]. 


\section{Seafloor basalt alteration by abiotic and biotic processes}

Alteration of basalt glass by seawater occurs by abiotic and biotic processes, but their partitioning is still not well known. The roughly $200,000 \mathrm{~km}^{2}$ occupied by seafloor basalts constitute by far the world's largest continuous microbial habitat [14]. It is generally accepted that microbe-basalt glass interactions control biogeochemical budgets, as well as the cycling of many elements (e.g., $\mathrm{C}, \mathrm{Fe}$; $[14,15])$ between seawater, the ocean crust and the upper mantle. Exposure of fresh basalt to seawater results in abiotic alteration and surface coverage by epilithic [surface dwelling] microbial communities. The former process produces $\mu \mathrm{m}$-sized dissolution features (cavities, crevices, pores) that are then rapidly colonized and exploited by endolithic [pore space dwelling] microorganisms [16]. The ubiquitous association of Fe and Mn-oxyhydroxides with basaltic seafloor crust arguably points to the pervasive action of microorganisms.

As with abiotic alteration, biotic processes in seawater both oxidize and hydrate basalt glasses. Exposed glassy rinds of basaltic seafloor lavas on the East Pacific Rise, for example, are characterized by a distinct microbiome, made of up to $10^{9}$ cells of Proteobacteria (88-96 \%) and Archaea per gram of rock [17]. This abundance is $10^{3}-10^{4}$ times greater than in adjacent overlying seawater [17]. The distinct nature of basalt microbiomes is also evidenced at Arctic spreading ridges [18] and the Juan de Fuca ridge flank [19]. In general, the predominant bacterial phylum is variable and depends not only on local conditions and specific mineralogy, but also on the age of the basalts [18]- this possibly points to an effect related to the degree of alteration.

The importance of abiotic and biotic alteration is likely similar up to $90{ }^{\circ} \mathrm{C}$ [20], beyond which the survival rate of microorganisms falls off. Estimates indicate that $70-80 \%$ of all glass alteration is biologically mediated within the upper $250 \mathrm{~m}$ of the ocean crust, whereas this process becomes minor $(<10 \%)$ at depths greater than $500 \mathrm{~m}[13]$.

Colonizing microbes create two principal types of microscale textures [21]: (i) granular clusters emanating from crack walls, characterized by $0.5-2 \mu \mathrm{m}$-sized nearly spherical voids that are often filled with authigenic clays and Fe-(oxy)hydroxides [13]; (ii) less commonly, worm-like tubular structures [22] a few $\mu \mathrm{m}$ in diameter and up to $100 \mu \mathrm{m}$ in length. The latter can often have complex spiral geometries [13]. It has been proposed that biotic alteration starts with granular dissolution, which can eventually be superseded by tubular alteration [23]. Interestingly, basalt glass weathering 
in a subglacial environment on Iceland is also characterized by spherical vesicles, with granular clusters extending from palagonite rind into the fresh glass [24]; however, very elongated tubes and long channel structures apparently do not form.

\section{Alteration enhancement by microorganism metabolic processes}

Given the absence of sunlight, bacterial and archaeal assemblages in contact with seafloor basalts derive their energy from chemical reactions involving inorganic compounds, and their carbon from inorganic sources. These chemolithoautotrophic reactions are the basis of biomass production and microbial diversity [17]. Two principal types of metabolic chemical processes take place. The first is biotic methanogenesis $[18,19]$, which is mediated exclusively by Archaea with specific enzymes [25]:

$\mathrm{CO}_{2}+4 \mathrm{H}_{2} \Rightarrow \mathrm{CH}_{4}+2 \mathrm{H}_{2} \mathrm{O},(1)$

where $\mathrm{CO}_{2}$ actually exists as $\mathrm{HCO}_{3}{ }^{-}$in deep sea environments. The source of $\mathrm{H}_{2}$ can be either microbial or inorganic (the latter either by water radiolysis or by serpentinization reactions of olivines and pyroxenes; [25]). Methanotrophic bacteria and Archaea will, in turn, partially consume the methane that is produced [25]. Redox reactions are the basis for the second type of metabolic process: oxidation of iron [17,18], manganese [15] and sulfur [17]; reduction of sulfate [19], iron and manganese [18]. Basalts are composed of minerals rich in reduced metals, such as $\mathrm{Fe}^{2+}$ and $\mathrm{Mn}^{2+}$, as well as of minor amounts of metal sulfides $\left(\mathrm{S}^{-2}\right)$; all of these reduced elements can serve as electron donors for chemolithotrophic communities. Enzymes, which are macromolecular biological proteins found in cellular membranes and cytoplasm, play a pivotal role in speeding up chemical reaction rates that are vital for the metabolic activity of microorganisms [26].

The important question is how metabolic reactions of microbes chemically alter and dissolve basaltic glass. Part of the answer is that abiotic and biotic processes work in tandem, but generally at different rates. Abiotic dissolution of basalt glass at deep seafloor conditions, i.e, low temperatures and circumneutral to weakly alkaline $\mathrm{pH}$ conditions, is slow but nonetheless effective in releasing basalt cations, namely $\mathrm{Si}, \mathrm{Al}, \mathrm{Ca}, \mathrm{Fe}, \mathrm{Mn}$ and $\mathrm{Mg}$. Once released into solution (seawater), reduced metals such as $\mathrm{Fe}^{2+}$ and $\mathrm{Mn}^{2+}$ are subject to oxidization, both abiotically by oxygen and nitrate, as well as by microbial enzyme-mediated reactions [17]. The abiotic and biotic 
conversion of $\mathrm{Fe}^{2+}$ to $\mathrm{Fe}^{3+}$ in solution promotes iron release from the solid. In addition, a direct biotic mechanism also exists — in this case the oxidation of reduced metals is enzymatically catalyzed at the microbe-glass interface. In situ oxidation of these metals affects their chemical bonding within the solid, thereby favoring their release and, thus, the overall dissolution of the glass. Moreover, oxidation of Fe and Mn results in the precipitation of metal-oxyhydroxides (e.g., $\mathrm{FeOOH}$ ), which ubiquitously occur in association with basaltic ocean crust. Other prokaryotic microorganisms then use these same phases to reduce oxidized metals.

In general, biomediated redox reactions not only satisfy the energy needs of microbes, thereby allowing them to survive and reproduce, but they also speed up these reactions compared to their abiotic counterparts. The electrons liberated by the oxidation of these elements serve to reduce $\mathrm{CO}_{2}$, producing elemental $\mathrm{C}$. The importance of microbial $\mathrm{C}$ fixation in deep sea floor basalts is supported by biomass calculations, which indicate that microorganisms can fix up to $510^{11} \mathrm{gCyr}^{-1}$, based on the assumption that the oxidation of $\mathrm{Fe}$ and $\mathrm{S}$ in the ocean crust is entirely due to microorganisms [27]. This result thus emphasizes the importance of basalt-microbe reactions with respect to the terrestrial carbon cycle.

Other types of interactions mediated by microorganisms also play a potential role in the chemical alteration of basalt. Extracellular polymeric substances (EPS), which are mainly composed of polysaccharides and proteins, encapsulate bacteria and Archaea and allow them to adhere to inorganic substrate (rock) surfaces. They contain carboxylic acid groups that can potentially increase chemical alteration by lowering the $\mathrm{pH}$ at the microbe-substrate interface. In addition, polysaccharides form ligand-metal complexes in solution, which can also increase dissolution rates $[16]$.

Microorganisms also produce (via enzymatic reactions) and secrete a variety of chemical compounds that can have a direct affect on basalt glass alteration. Chemical ligands are one such group of compounds. These ions or molecules, which form coordinated complexes with a central metal atom, bond with certain surface atoms of the solid substrate, thereby disrupting their chemical linkages and facilitating release to solution. There is an apparent positive correlation between the microbial production of organic ligands and the release rate of $\mathrm{Si}, \mathrm{Al}$ and $\mathrm{Fe}$ [16] from silicates. In addition to this effect, ligand complexes in solution serve to shift the solution saturation state away 
from chemical equilibrium, thereby increasing metal release rates from solids. Iron-specific ligands called siderophores form very strong $\mathrm{Fe}^{3+}$-chelating compounds. They can bond to surface iron sites and catalyze their release to solution [15], thereby making $\mathrm{Fe}^{+3}$ available for eventual metabolic reactions by organisms. Enzymatic reactions also produce organic acids, which microbes passively or actively excrete- this process can also directly enhance glass dissolution. This effect is particularly effective in crevasses and pore spaces inhabited by microbes, where very low pH values have been measured, thereby theoretically increasing dissolution rates by factors of 10-1000 (e.g., pH 3.4 in pore space vs 7.0 in bulk solution, [28]). Aside from secreted acids, dissolved microbial metabolic products are also known to be acidic in nature, and can therefore also enhance dissolution rates.

\section{Biotic corrosion models}

A generalized model of a biologically mediated corrosion processes is shown in Fig. 1 [13]. The formation of granules and elongated tubes results from localized congruent dissolution by endolithic microbes that produce complexing agents, enzymes, siderophores, and acidic $\mathrm{pH}$ fluids. The $\mathrm{pH}$ in localized microenvironments is thought to be lower than in the surrounding seawater [22], and the dissolution process is assumed to be congruent, as apparently deduced from the lack of a palagonite gel. The principal alteration products are insoluble and organic matter deposited on the granule and tunnel walls, whereas authigenic mineral phases precipitate on surfaces exposed to seawater. The tunneling action of the filamentous extension of the microbe (Fig. 1c), similar to mycelium of fungi, is due to the secretion of acids and complexing agents at the tips of individual filaments. Dissolved nutrients and metabolic (waste) products are transported away from the dissolution front within the filaments themselves. Although the presence or absence of palagonite at the interface with the pristine glass (Fig. 1) cannot be evaluated, this generalized model based on congruent glass alteration concurs with the CIDR model.

In the same study, alteration localized at cracks was also investigated [13]. As revealed by $\mu$ m-scale elemental mapping by electron probe microanalysis, the edges of cracks from which granules originated exhibit a depletion of $\mathrm{P}, \mathrm{Ca}$ and $\mathrm{Mg}$, suggesting the formation of a cation-depleted palagonite layer at the interface with the pristine glass. Mapping of tubular structures emanating 
from a crack and penetrating into pristine glass was also done with synchrotron-based X-ray spectroscopy (EDX). Overall, these data point to cation loss from the glass and enrichment of other cations in regions occupied by the putative microbes. Owing to the $\mu \mathrm{m}$-spatial resolution of these analyses, a more precise evaluation of the corrosion process is not possible.

Granular and tubular structures of assumed microbial origin have been examined at relatively high spatial resolution with TEM techniques, which include energy dispersive X-ray spectroscopy (EDX) and selected area electron diffraction (SAED). In a 6-Ma old glass retrieved from east Pacific crust (Fig. 2), spherical and vermicular structures extend into the fresh glass and are typically composed of 100-300 nm-wide altered glass rinds depleted in $\mathrm{Mg}, \mathrm{Mn}, \mathrm{Fe}, \mathrm{Ca}$ and $\mathrm{Na}$, and enriched in Si, Al, Ti and K [29]. The granular texture likely resulted from microbe enhanced dissolution of the glass, leaving behind open tubular structures. Continued incongruent dissolution of the glass led to precipitation of phyllosilicates (primarily smectite) in the open tubes, or alternatively, the smectite could have formed by in situ replacement of the altered glass. As for the mechanisms involved, an incongruent dissolution process was suggested to yield palagonite, although the structural interfaces of palogonite with both the glass and phyllosilicate appear to be relatively sharp (Fig. 2). In reality, these interfaces might have been even sharper had higher resolution imaging been achieved, thus making it possible to speculate on an interfacial reprecipitation process (CIDR). In any case, the resemblance of the spherical dissolution features attributed to biologically mediated alteration in Fig. 2 with the abiotic formation of the spherical palagonite in Fig. 5 is remarkable.

Other insights are possible from a study of tubules in 4 basalt glass samples with different provenances and ages, using various high-resolution TEM techniques [30]. With structures similar to those in Fig. 2, images show the presence of fresh glass, a 20-50 nm-thick palagonite layer, and a core region containing phyllosilicates. The palagonite is depleted in $\mathrm{Ca}, \mathrm{Fe}, \mathrm{Mg}, \mathrm{K}$, and $\mathrm{Mn}$, but enriched in Si and O, and has very sharp structural and chemical boundaries with the fresh glass and phyllosilicates at the internal and external interfaces, respectively. Without supporting or repudiating a biological origin of the palagonite present in the tubules, the authors suggested that the palagonite developed by incongruent dissolution and preferential cation leaching, followed by precipitation of phyllosilicates from a saturated solution, or by in situ transformation of unstable 
palagonite [30]. Notwithstanding their interpretation, the measured Si-enrichment in the palagonite, as well as the sharp chemical and structural interfaces, agree far better with the CIDR mechanism, which would imply that the palagonite layer formed as an interfacial reprecipitate.

In another detailed study, basalt tubules investigated at the $\mu \mathrm{m}$-scale with three synchrotron X-ray methods revealed depletion in $\mathrm{Fe}^{2+}, \mathrm{Ca}^{2+}$ and $\mathrm{Mn}^{2+}$, enrichment in $\mathrm{Ti}$ and $\mathrm{Cu}$, and oxidation of residual iron to $\mathrm{Fe}^{3+}$ [31]. The tubule mineralogy is dominated by $\mathrm{Fe}^{3+}$-silicates from the smectite group of clays. Whereas the biogenicity of the tubular structures remained an open question, the mechanism leading to their formation could not be unambiguously elucidated because of the insufficient spatial resolution of the analyses.

Alternatively, congruent element release and palagonite formation (Fig. 3) were surmised during the chemical weathering of basalt glasses, presumably by microorganisms [32]. The palagonite occupying the tubular structures is composed primarily of insoluble Fe and Ti phases, and is separated from the glass by a gap (up to $5 \mu \mathrm{m}$ ) attributed to the pronounced loss of Si to the fluid. The physical gap [33-35] supports a CIDR process, and not preferential cation leaching. Interestingly, micrographs at the micron-scale show that the outer edges of the glass, as well as plagioclase phenocrysts, are characterized by $1 \mu \mathrm{m}$-thick light colored bands with distinct boundaries running parallel to the edges. These bands may in fact represent successive dissolution-reprecipitation events, but this idea would require additional work using analytical techniques with nm to sub-nmscale resolution.

To determine the role of microorganisms in the low-temperature alteration of a 122 Ma seafloor basaltic glass, tubular and vermicular micro-channels were investigated at the nm-scale by a combination of analytical techniques, such as FIB-TEM and scanning transmission X-ray microscopy (SXTM) [36]. The micro-channels cutting through the fresh glass have $30 \mathrm{~nm}$-wide Sirich rims, followed by palagonite with partially oxidized Fe, as well as organic carbon associated with nm-sized carbonate grains. The formation of the silica rims was attributed to incongruent dissolution and preferential cation leaching of the glass (see Figs. 1-3, Ch. 5.12), which preceded the formation of the palagonite. However, two notable indices favor the CIDR mechanism: a) the silica-rich rims have very sharp interfaces with the basalt glass and palagonite; b) there are abrupt, step-like changes in Si concentration between the glass and the Si-rich rim (see Fig. 7, 8, Ch 5.12). 


\section{Abiotic corrosion models}

The first step in abiotic corrosion has been stated to be hydration and chemical exchange with seawater, leading to the formation of a palagonite gel by interdiffusion of preferentially leached glass cations with chemical species from seawater, including $\mathrm{H}_{3} \mathrm{O}^{+}$[13]. Further alteration leads to precipitation of clays, zeolites and iron oxy-hydroxides on the palagonite gel (Fig. 4). This scenario fits the interdiffusion leached-layer mechanism if the interdiffusive zone and gel are considered as the palagonite (Figs. 1-3, Ch. 5.12). From high-resolution TEM images [37], the formation of palagonite was described in similar terms: incongruent glass dissolution in fracture domains leading to leached layers several tens of $\mathrm{nm}$ in thickness. Eventually, the Al and Si-enriched leached layers are transformed in situ to smectite. The overall palagonitization process is characterized by a loss of $\mathrm{Fe}, \mathrm{Mg}$, and $\mathrm{Ca}$, and a gain in $\mathrm{Al}$, with $\mathrm{Si}$ enrichment being strictly restricted to the leached layer. In a striking example of a glass alteration sequence (Fig. 5a), the structural and compositional interfaces between a palagonite rind and glass are very sharp [38]. In addition, the palagonite appears to have several concentric layers delimited by sharp boundaries. A distinct phyllosilicate layer formed at the outer palagonite interface during continued alteration. Palagonitization was associated with the creation of significant secondary porosity, and was therefore thought to involve a non-isovolumetric process- a key characteristic of CIDR [39]. Although the intrinsic mechanism of alteration and palagonite formation was not specifically addressed, the sharpness of the glasspalagonite interface, as well as the sharply delimited concentric palagonite layers, also support the CIDR process (Fig. 6, Ch. 5.12). The chemical profiles in Fig. 5b cannot, however, be used to discriminate between the leached layer and CIDR models because of their low spatial resolution. In another model [10], the first step in volcanic glass corrosion is the formation of a yellowishbrown amorphous gel (palagonite) rind that armors the fresh glass. The gel forms from the congruent dissolution of the glass and contemporaneous precipitation of a gel depleted in $\mathrm{Si}, \mathrm{Al}$, $\mathrm{Mg}, \mathrm{Ca}, \mathrm{Na}$ and $\mathrm{K}$, enriched in $\mathrm{H}_{2} \mathrm{O}$, and 'passively' enriched in Ti and Fe. At the $\mu \mathrm{m}$-scale, the sharp and distinct physical interface separating the glass from the palagonite (Fig. 6) again concurs with key features of the CIDR mechanism, namely a sharp interface, congruent release of glass cations, and coupled reprecipitation. Because the first-formed palagonite gel is unstable, further 
reaction with the surrounding fluid (seawater) results in the crystallization of smectite clays at the expense of the palagonite at its external surface (stage AGS I- Fig. 6). Further alteration causes most of the remaining palagonite to be converted to smectite (stage AGS II) and other authigenic minerals.

The effect glass composition is illustrated in a study [8] of the alteration of interstitial glasses of various ages, composed mainly of $\mathrm{SiO}_{2}$ and $\mathrm{Al}_{2} \mathrm{O}_{3}$, which produced a Mg-rich smectite clay called

saponite. The $10 \AA$-lattice fringes of saponite observed by TEM in nm-proximity to the unaltered glass supports direct formation from the glass without a palagonite precursor phase, but whether there was a very thin intermediate gel-like phase between the glass and saponite is not known. If it did form at the expense of the glass via a solution-mediated transformation, then this process can be considered within the framework of the CIDR mechanism. However, saponite precipitation from an oversaturated bulk solution cannot be excluded.

In a completely different view concerning both abiotic and biotic corrosion [40], granular palagonite textures and tubular etch tunnels in basalt glass are linked to damage to the glass structure caused by radioactive decay of $U$ and $T h$, which are trace elements in all basalts. Selective dissolution of alpha-recoil and fission tracks is shown to yield abiotic granular and tubular structures mimicking biotic alteration textures (Fig. 7). As for the filaments that are frequently observed and often considered to be of biological origin, the authors argued that they might in fact be long tubular strands of imogolite, a secondary aluminum silicate clay mineral $\left[\mathrm{Al}_{2} \mathrm{SiO}_{3}(\mathrm{OH})_{4}\right]$ [40]. On the other hand, certain types of complex tubular textures, such as micro-tunnels with spiral/helical, annulated, dendritic, and palmate structures cannot be attributed to dissolution of radiation-damaged glass [40], or any other known abiotic corrosion process. Nonetheless, the lack of nm-scale chemical and structural data in this study precludes identifying any specific alteration mechanism.

\section{The abiotic vs. biotic alteration debate}

The possibility that seafloor basalts have preserved traces of biotic chemical weathering up to 3.5 billion years old [13] is one of the most central issues concerning Earth's early evolution. This explains why studies of seawater alteration of basalt glasses have been largely devoted to the thorny 
issue of differentiating abiotic and biotic alteration signatures. Chemical and structural criteria have been proposed for the assignment of tubular structures to bioalteration [13]. The principal argument in favor of biogenicity is that granular, and in particular, complex tubular structures, are not likely to form from an abiotic dissolution process. In addition, chemical analyses of tubes in basalt glasses have evidenced enrichment in certain elements $(\mathrm{C}, \mathrm{N}, \mathrm{P})$ and DNA fragments [13]. This implies that organisms had been present therein at one point in time, although this is not absolute proof that they created the actual tubes. In fact, it has been impossible to link directly specific microorganisms to granular and tubular textures found in altered glasses, e.g., [23].

Even the use of very advanced nanometer-scale analytical techniques did not allow for the discrimination between an abiotic or biotic origin for micro-channels in ancient seafloor basalt glasses [36]. The debate is particularly tenuous with respect to putative biological tubular structures in glasses dating to the Archean (4-2.5 billion years) [13,23,36,41,42]. For example, a recent study [23] shows a convincingly close physical resemblance between tubular structures found in a fresh glass from the Troodos ophiolite and tubular structures replaced by titanite $\left[\mathrm{CaTiSiO}_{5}\right]$ from the Barberton greenstone belt (metamorphosed basalts with ages up to $3.6 \mathrm{Ga}$ ). On the other hand, a detailed study of titanite-bearing microtubes in an Archean volcanic ash did not yield solid evidence in favor of bioalteration when examined with submicrometer-resolution methods [41].

Adding to the debate, microbial culture studies provide evidence that bacteria growing on basalt glasses do play a direct role in the release of $\mathrm{Si}, \mathrm{Fe}$ and $\mathrm{Mn}$ to solution [43]; however, their overall degree of contribution to dissolution still remains largely unknown [15]. Notwithstanding, globular and tubular structures have never been replicated in the laboratory [31], but this may be simply due to the extreme slowness of biotic alteration.

\section{Which mechanism controls basalt glass corrosion?}

The studies concerning biotic and abiotic alteration of basalt glasses present for the most part $\mu \mathrm{m}$ scale cross sectional images and chemical analyses of pristine basalt glass, palagonite, secondary authigenic minerals, and putative microbial remnants. Can these results be used to support one or the other alteration mechanism? 
No single mechanism could be deduced from the abiotic group. In some studies a corrosion mechanism was not proposed [38,40], or an incongruent dissolution-leached layer mechanism $[13,37]$ was simply assumed. Others argued for palagonite formation through coupled congruent dissolution-precipitation (i.e., CIDR) [10], or direct transformation of glass into sapponite [8]. For the latter, one cannot rule out precipitation of sapponite from a saturated solution, or alternatively, transformation of a precursor palagonite into sapponite. Interestingly, hallmarks of CIDR have been reported in the abiotic group, such as $\mathrm{Al}$ and Si-enriched secondary layers [37], or secondary porosity and/or sharp interfaces $[8,10,38]$.

In the biotic group, the granular and tubular structures are not associated with unequivocal evidence in favor of one or the other corrosion mechanism. Whereas a specific mechanism could not be confirmed in one case [31], four others argued for initial corrosion by preferential cation release $[13,29,30,36]$. Another investigation [32], as well as the general model in [13], proposed congruent dissolution followed by precipitation. As with the abiotic studies, several studies actually did show sharp interfaces and Si-rich glass corrosion rims that fit best with the CIDR model [29,30,32,36]. Both the abiotic and the biotic corrosion studies considered the formation of secondary authigenic crystalline phases, in particular phyllosilicate minerals, in terms of two processes, namely, precipitation from a saturated solution and in situ transformation of palagonite or fresh glass. In all cases, the authigenic minerals that occupy granular and tubular structures have very sharp interfaces with palagonite or glass, e.g., [29,38]. Sharp chemical and structural interfaces are strong evidence for the CIDR mechanism (Ch. 5.12, see also [35,44,45]).

\section{Perspectives}

The precise molecular-scale mechanism controlling the abiotic and biotic alteration of basaltic glasses in seawater remains an open question. To date, most seawater-basalt glass studies have used analytical approaches with spatial resolutions in the $\mu \mathrm{m}$ to sub- $\mu \mathrm{m}$-range, making it problematical to define the operative mechanism controlling alteration. Only a few studies, e.g., [30,36], have published chemical and structural data at the nm-scale. Further progress in this field will thus certainly depend upon detailed investigations of glass alteration using more advanced, highresolution analytical techniques. As described in Ch. 5.12, how glass samples are prepared and 
which analytical techniques are used is of critical importance for deciphering the molecular-scale mechanism of alteration. These tools will ultimately permit identifying the actual glass corrosion mechanism, and hopefully, may even help in the debate on deciphering abiotic and biotic alteration signatures. Of course, chemical, isotope and structural data obtained at the nanometer scale should also be used in a complementary manner with large scale mass balance calculations, and perhaps even be integrated into thermodynamic-kinetic models to be used as predictive tools for understanding basalt glass-seawater interactions over long periods.

\section{Acknowledgements}

The author thanks A.-M. Karpoff, O. Majerus, G.E. Bebout and J. Martins for their useful comments and suggestions.

\section{Index terms}

Volcanic basalt glass, MORB, interstitial basalt glass, sideromelane, biotic and abiotic alteration, cation depleted leached layer-interdiffusion mechanism, coupled interfacial dissolutionreprecipitation mechanism (CIDR), palagonite, gel, surface altered layer, hydrated layer, authigenic mineral, phyllosilicate, smectite, zeolite, Fe-oxyhydroxide, microbes, bacteria, Archaea, borosilicate glass, carbonation reaction, granular and tubular dissolution structures 


\section{References}

1. H. Staudigel and S.R. Hart, Alteration of basaltic glass: processes and significance for the oceanic crust-seawater budget, Geochim. Cosmochim. Acta, 47 (1983) 337-50.

2. P.V. Brady and S.R. Gíslason, Seafloor weathering controls on atmospheric $\mathrm{CO}_{2}$ and global climate, Geochim. Cosmochim. Acta, 61 (1997) 965-73.

3. D. Chavrit et al., The contribution of hydrothermally altered ocean crust to the mantle halogen and noble gas cycles, Geochim. Cosmochim. Acta, 183 (2016) 106-24.

4. D.S. Goldberg, T. Takahashi and A.L. Slagle, Carbon dioxide sequestration in deep-sea basalt, Proc. Natl. Acad. Sci. USA, 105 (2008) 9920-25.

5. A.P. Gysi and A. Stefánsson, Mineralogical aspects of $\mathrm{CO}_{2}$ sequestration during hydrothermal basalt alteration - An experimental study at 75 and $250{ }^{\circ} \mathrm{C}$ and elevated $p \mathrm{CO}_{2}$. Chem. Geol., 306-307 (2012) 146-59.

6. A.P. Gysi and A. Stefánsson, $\mathrm{CO}_{2}$-water-basalt interaction. Low temperature experiments and implications for $\mathrm{CO}_{2}$ sequestration into basalts, Geochim. Cosmochim. Acta, 81 (2012) 129-52.

7. J.-L. Crovisier, T. Advocat and J.-L. Dussossoy, Nature and role of natural alteration gels formed on the surface of ancient volcanic glasses (Natural analogs of waste containment glasses), $J$. Nucl. Mater., 321 (2003) 91-109.

8. W. Zhou, D.R. Peacor, J.C. Alt, R. van der Voo and L.S. Kao, TEM study of the alteration of interstitial glass in MORB by inorganic processes, Chem. Geol., 174 (2001) 365-76.

9. W.S. von Waltershausen, Über die submarinen Ausbrüche in der tertiären Formation des Val di Noto im Vergleich mit verwandten Erscheinungen am Ätna, Gött. Stud., 1 (1845) 371-431.

10. N.A. Stroncik and H.-U. Schmincke, Evolution and palagonite: Crystallization, chemical changes, and element budget, Geochem. Geophys. Geosyst., 2 (2001) 2000GC000102.

11. N.A. Stroncik and H.-U. Schmincke, Palagonite - a review, Int. J. Earth Sci. (Geol. Rundsch.), 91 (2002) 680-97.

12. N. McLoughlin, D. Wacey, C. Kruber, M.R. Kilburn, I.H. Thorseth and R.B. Pedersen, A combined TEM and NanoSIMS study of endolithic microfossils in altered seafloor basalt, Chem. Geol., 289 (2011) 154-62. 
13. H. Staudigel, H. Furnes, N. McLoughlin, N.R. Banerjee, L.B. Connell and A. Templeton, 3.5 billion years of glass bioalteration: Volcanic rocks as a basis for microbial life?, Earth-Sci. Rev., 89 (2008) 156-76.

14. J.B. Sylvan, A.G. Turner and K.J. Edwards, Microbe-metal interactions on seafloor basalts, p. 65-76 in J.F. Stolz and R.S. Oremland (eds), Microbial Metal and Metalloid Metabolism: Advances and Applications (Washington, D.C.: ASM Press, 2011).

15. L.A. Sudek, G. Wanger, A.S. Templeton, H. Staudigel and B.M. Tebo, Submarine basaltic glass colonization by the heterotrophic Fe(II)-oxidizing and siderophore-producing deep-sea bacterium Pseudomonas stutzeri VS-10: The potential role of basalt in enhancing growth, Front. Microbiol., 8 (2017) 1-12.

16. J.F. Banfield, W.W. Barker, S.A. Welch and A. Taunton, Biological impact on mineral dissolution: Application of the lichen model to understanding mineral weathering in the rhizosphere, Proc. Natl. Acad. Sci. USA, 96 (1999) 3404-11.

17. C.M. Santelli et al., Abundance and diversity of microbial life in ocean crust, Nature, 453 (2008) 653-657.

18. K. Lysnes, I.H. Thorseth, B.O. Steinsbu, L. Øvreås, T. Torsvik and R.B. Pedersen, Microbial community diversity in seafloor basalt from the Arctic spreading ridges, FEMS Microbiol. Ecol. 50 (2004) 213-230.

19. S.P. Jungbluth, R.M. Bowers, H.-T. Lin, J.P. Cowen and M.S. Rappé, Novel microbial assemblages inhabiting crustal fluids within mid-ocean ridge flank subsurface basalt, The ISME J., 10 (2016) 2033-2047.

20. H. Furnes and H. Staudigel, Biological mediation in oceanic crust alteration: how deep is the deep biosphere?, Earth Planet. Sci. Lett., 166 (1999) 97-103.

21. M.R. Fisk, S.J. Giovannoni and I. Thorseth, Alteration of oceanic volcanic glass: textural evidence of microbial activity, Science, 281 (1998) 978-80.

22. I.H. Thorseth, H. Furnes and M. Heldal, The importance of microbiological activity in the alteration of natural basaltic glass, Geochim. Cosmochim. Acta, 56 (1992) 845-50.

23. H. Staudigel, H. Furnes and M. Smits, Deep biosphere record of in situ oceanic lithosphere and ophiolites, Elements, 10 (2014) 121-26. 
24. C. S. Cockell, K. Olsson-Francis, A. Herrera and A. Meunier, Alteration textures in terrestrial volcanic glass and the associated bacterial community, Geobiology, 7 (2009) 50-65.

25. R. Kietäväinen and L. Purkamo, The origin, source, and cycling of methane in deep crystalline rock biosphere, Front. Microbiol., 6 (2015) 725.

26. E.H. Roden, Microbiological controls on geochemical kinetics 1: Fundamentals and case study on microbial Fe (III) oxide reduction, p. 335-415 in S.L. Brantley, J.D. Kubicki and A.F. White (eds), Kinetics of Water-Rock Interaction (New York: Springer, 2008).

27. W. Bach and K.J. Edwards, Iron and sulfide oxidation within the basaltic ocean crust: Implications for chemolithoautotrophic microbial biomass production. Geochim. Cosmochim. Acta 67 (2003) 3871-87.

28. W.W. Barker, S.A., Welch, S. Chu and J.F. Banfield, Experimental observations of the effects of bacteria on aluminosilicate weathering, Amer. Mineral. 83 (1998) 1551-63.

29. J.C. Alt and P. Mata, On the role of microbes in the alteration of submarine basaltic glass: a TEM study, Earth Planet. Sci. Lett., 181 (2000) 301-13.

30. E. Knowles, R. Wirth and A. Templeton, A comparative analysis of potential biosignatures in basalt glass by FIB-TEM, Chem. Geol., 330-331 (2012) 165-75.

31. E. Knowles, H. Staudigel and A. Templeton, Geochemical characterization of tubular alteration features in subseafloor basalt glass, Earth Planet. Sci. Lett., 374 (2013) 239-50.

32. S. Dultz et al., Alteration of a submarine basaltic glass under environmental conditions conducive for microorganisms: Growth patterns of the microbial community and mechanism of palagonite formation, Geomicrobiol. J., 31 (2014) 813-34.

33. T. Geisler et al., The mechanism of borosilicate glass corrosion revisited, Geochim. Cosmochim. Acta, 158 (2015) 112-29.

34. H.E. King, O. Plümper, T. Geisler and A. Putnis, Experimental investigations into the silicification of olivine: Implications for the reaction mechanism and acid neutralization, Amer. Mineral., 96 (2011) 1503-11.

35. R. Hellmann et al., Unifying natural and laboratory chemical weathering with interfacial dissolutionreprecipitation: A study based on the nanometer-scale chemistry of fluid-silicate interfaces, Chem. Geol., 294-295 (2012) 203-16. 
36. K. Benzerara, N. Menguy, N.R. Banerjee, T. Tyliszczak, G.E. Brown, Jr. and F. Guyot, Alteration of submarine basaltic glass from the Ontong Java Plateau: A STXM and TEM study, Earth Planet. Sci. Lett., 260 (2007) 187-200.

37. A. Drief and P. Schiffman, Very low temperature alteration of sideromelane in hyaloclastites and hyalotuffs from Kilauea and Mauna Kea volcanoes: Implications for the mechanism of palagonite formation, Clays Clay Minerals, 52 (2004) 623-35.

38. B.D. Pauly, P. Schiffman, R.A. Zierenberg and D.A. Clague, Environmental and chemical controls on palagonitization, Geochem. Geophys. Geosyst., 12 (2011) 1-26.

39. E. Ruiz-Agudo, C.V. Putnis and A. Putnis, Coupled dissolution and precipitation at mineral-fluid interfaces, Chem. Geol., 383 (2014) 132-46.

40. J.E. French and D.F. Blake, Discovery of naturally etched fission tracks and alpha-recoil tracks in submarine glasses: Reevaluation of a putative biosignature for Earth and Mars. Intl. J. Geophys., (2016) 2410573.

41. K. Lepot, K. Benzerara and P. Philippot, Biogenic versus metamorphic origins of diverse microtubes in 2.7 Gyr old volcanic ashes: Multi-scale investigations, Earth Planet. Sci. Lett., $312(2011) 37-47$.

42. H. Furnes, N.R. Banerjee, K. Muehlenbachs, H. Staudigel and M. de Wit, Early life recorded in Archean pillow lavas, Science, 304 (2004) 578-81.

43. K.J. Edwards, W. Bach, T.M. McCollom and D.R. Rogers, Neutrophilic iron-oxidizing bacteria in the ocean: their habitats, diversity, and roles in mineral deposition, rock alteration, and biomass production in the deep-sea, Geomicrobiol. J., 21 (2004) 393-404.

44. R. Hellmann et al., Nanometre-scale evidence for interfacial dissolution-reprecipitation control of silicate glass corrosion, Nature Mater., 14 (2015) 307-11.

45. R. Hellmann, J.-M. Penisson, R.L. Hervig, J.-H. Thomassin and M.-F. Abrioux, An EFTEM/HRTEM high-resolution study of the near surface of labradorite feldspar altered at acid $\mathrm{pH}$ : evidence for interfacial dissolution-reprecipitation, Phys. Chem. Miner., 30 (2003) 192-97. 


\section{Figure Captions}

Fig. 1. Biotic glass corrosion model results in granular textures (panel B) or tubular tunnels (panel C). The microbes mediate localized congruent dissolution, resulting in insoluble residual and organic matter, secondary authigenic minerals, but no palagonite. Adapted from Fig. 14, [13].

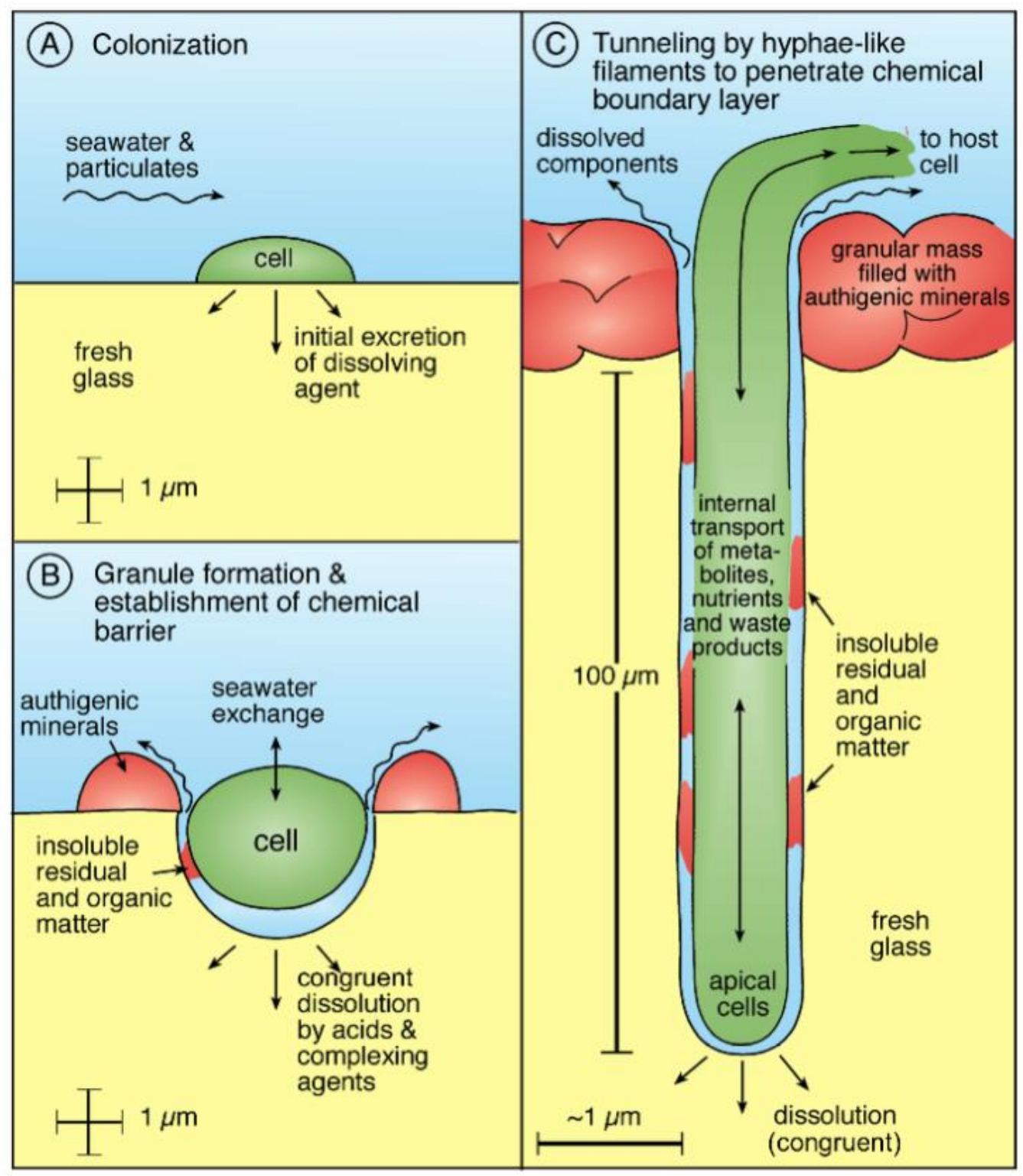


Fig. 2. Putative microbial alteration of glass. (a) TEM image of glass and a spherical alteration structure composed of palagonite rim and phyllosilicate core. (b) HRTEM image of palagonitephyllosilicate interface. Adapted from Fig. 2, [29].

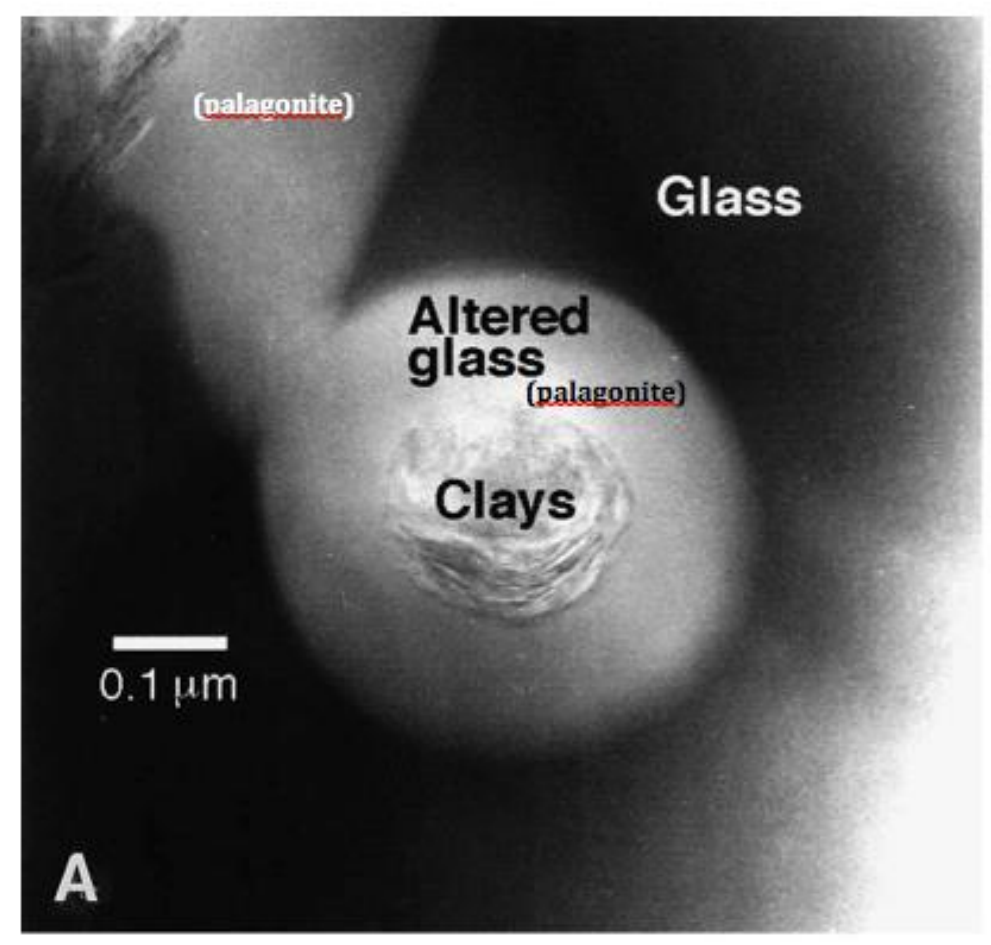

(palagonite)

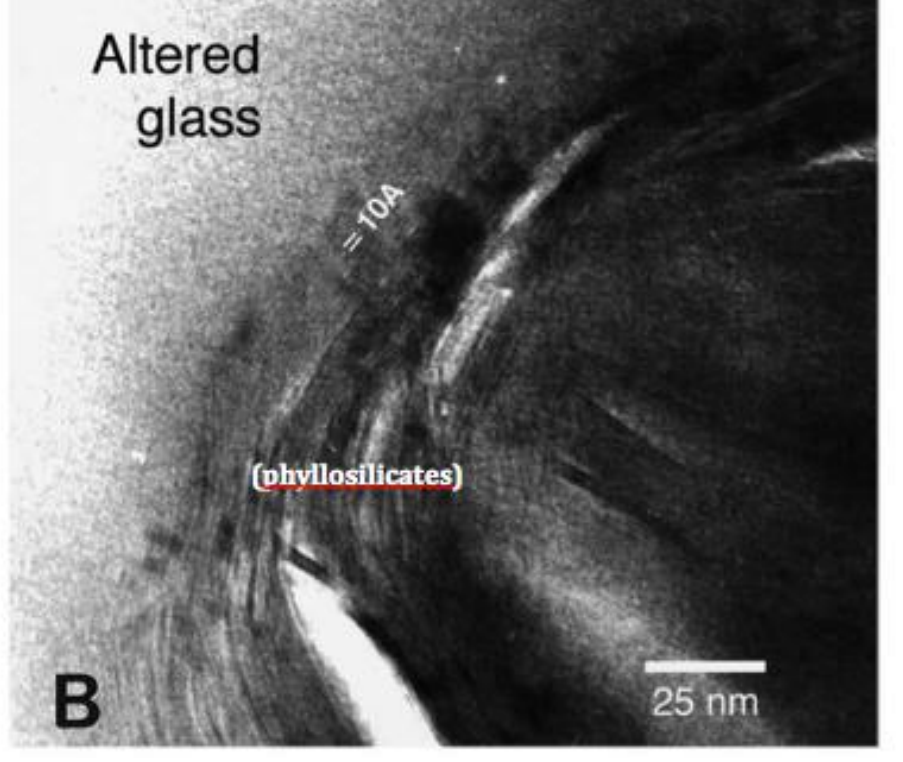


Fig. 3. Biologically-mediated glass alteration model based on congruent dissolution at selective sites colonized by microbes. Precipitation of a porous palagonite layer enriched in $\mathrm{FeO}, \mathrm{TiO}_{2}, \mathrm{P}_{2} \mathrm{O}_{5}$, and $\mathrm{K}$ from a saturated fluid; the solution gap is due to the release of $\mathrm{Si}$ and other elements ( $\mathrm{Al}, \mathrm{Na}$, $\mathrm{Mg}, \mathrm{Ca})$ from the glass. Adapted from Fig. 12, [32].

\section{Solution Palagonite layer}

\begin{tabular}{|c|c|}
\hline $\begin{array}{l}\text { reaction front } \\
\qquad \text { Glass } \\
\text { congruent } \\
\text { dissolution }\end{array}$ & 1 \\
\hline $\begin{array}{l}\text { D: Microorganisms } \backsim \text { : Compounds of palagonite layer } \\
\text { Transport of glass constituents: } \\
\longrightarrow \text { : Short range, deposition on the rim of palagonite layer } \\
\longrightarrow \text { : Medium range, deposition within the palagonite layer } \\
\rightarrow \text { : Long range, transfer to solution/diffusion through the } \\
\text { palagonite layer }\end{array}$ & $\begin{array}{l}\text { from the surrounding pore } \\
\text { water through the palagonite } \\
\text { layer. Sorption / chemical } \\
\text { reaction with the palagonite } \\
\text { and glass surface }\end{array}$ \\
\hline
\end{tabular}


Fig. 4. Abiotic alteration ( $\mathrm{t}_{0}-\mathrm{t}_{4}$, panels $\left.\mathrm{A}-\mathrm{E}\right)$. Palagonite rinds form at the expense of fresh glass by hydration and exchange with seawater cations (arrow, $\mathrm{t}_{0}$ ). Palagonite continuously consumes fresh glass $\left(t_{1}-t_{4}\right)$, while authigenic mineral precipitation decreases pore space $\left(t_{1}-t_{3}\right)$, finally sealing the rock $\left(t_{4}\right)$ to external fluids. Panel F: thin section of naturally altered hyaloclastite (Iceland), equivalent to $t_{2}$. Adapted from Fig. 1, [13].

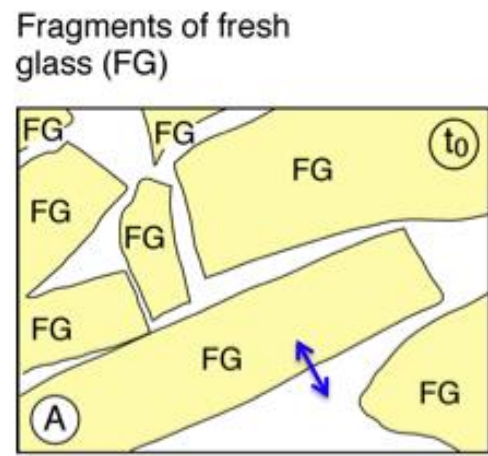

\section{Palagonite $(P)$ rinds} Authigenic (AM) minerals
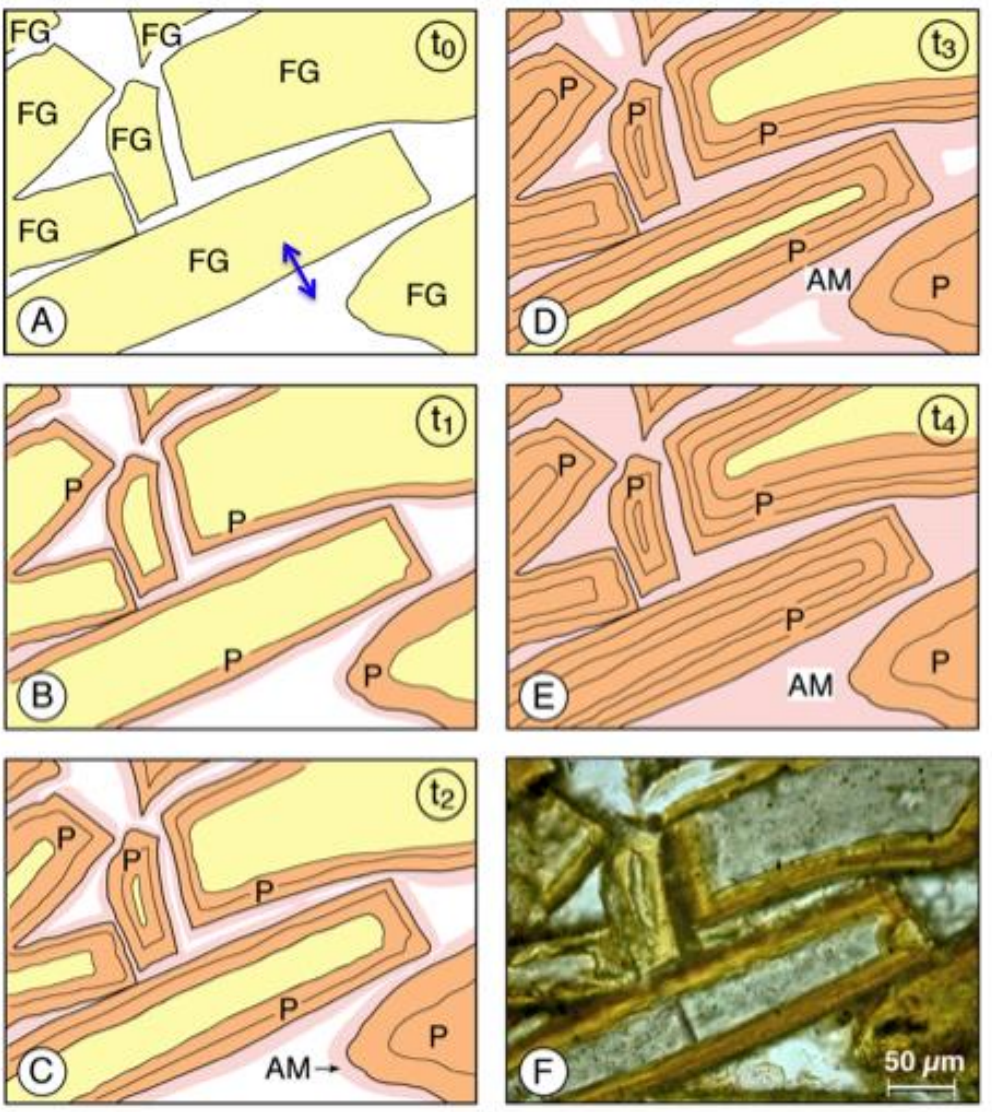
Fig. 5. Alteration of sideromelane [basaltic glass] by seawater. (a) SEM image: palagonite forms by dissolution of glass at sharp reactive interface (6) - note also sharp concentric banding within palagonite (thin black arrows) (b) Chemical profiles from vesicle edge to palagonite-glass interface (1-6 arrow). Mg enrichment is a signature of seawater. Adapted from Fig. 12, [38].

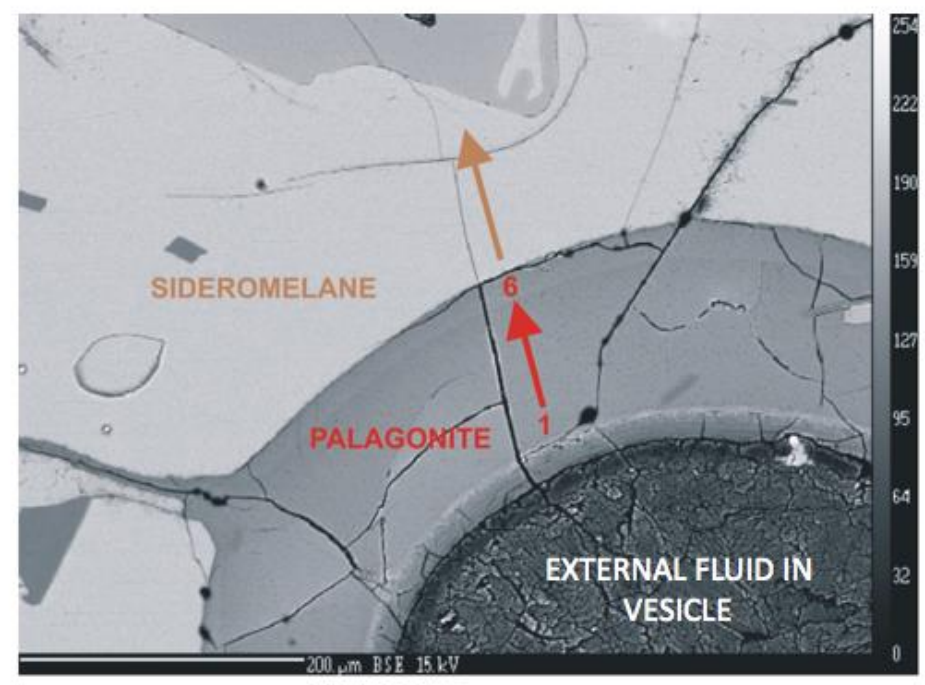

SOH-1 PALAGONITE MAJOR-ELEMENT CONCENTRATION TRAVERSE (Sample 4565; Grain 2)

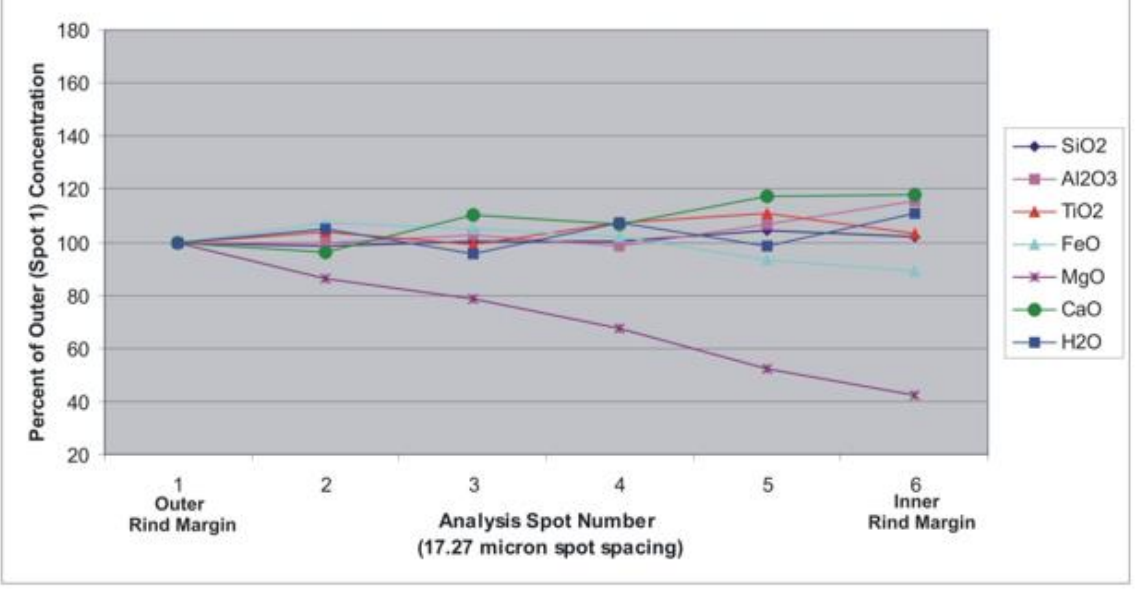


Fig. 6. Corrosion of glass and formation of palagonite by dissolution-reprecipitation. Stage 1: fresh glass (FG) congruently dissolves with simultaneous reprecipitation of palagonite (P). Palagonite continuously forms at the expense of glass. Stage 2: palagonite transforms in situ to smectite (AGS I, AGS II). Secondary authigenic minerals may also form. Adapted from Fig. 15, [10].

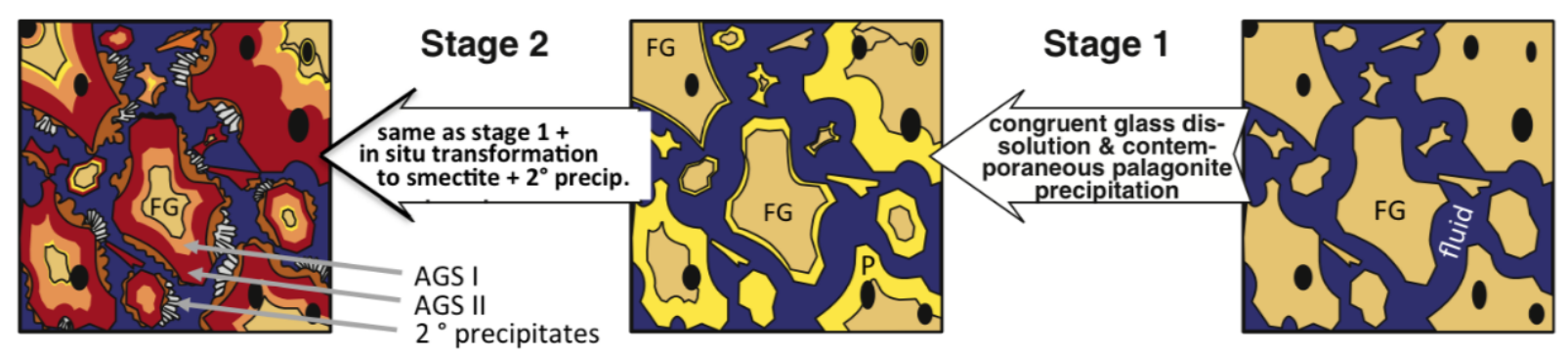


Fig. 7. Abiotic corrosion of basaltic glass. Palagonite rim initially forms in a seawater-filled fracture, followed by preferential dissolution of radiation-damaged sites, resulting in complex microtextures strongly resembling biotic textures. Last panel: granular palagonite alpha-recoil track alteration (GP(ART)); alpha-recoil track etch tunnels (ARTETs); fission track etch tunnels (FTETs). Adapted from Fig. 18, [40].

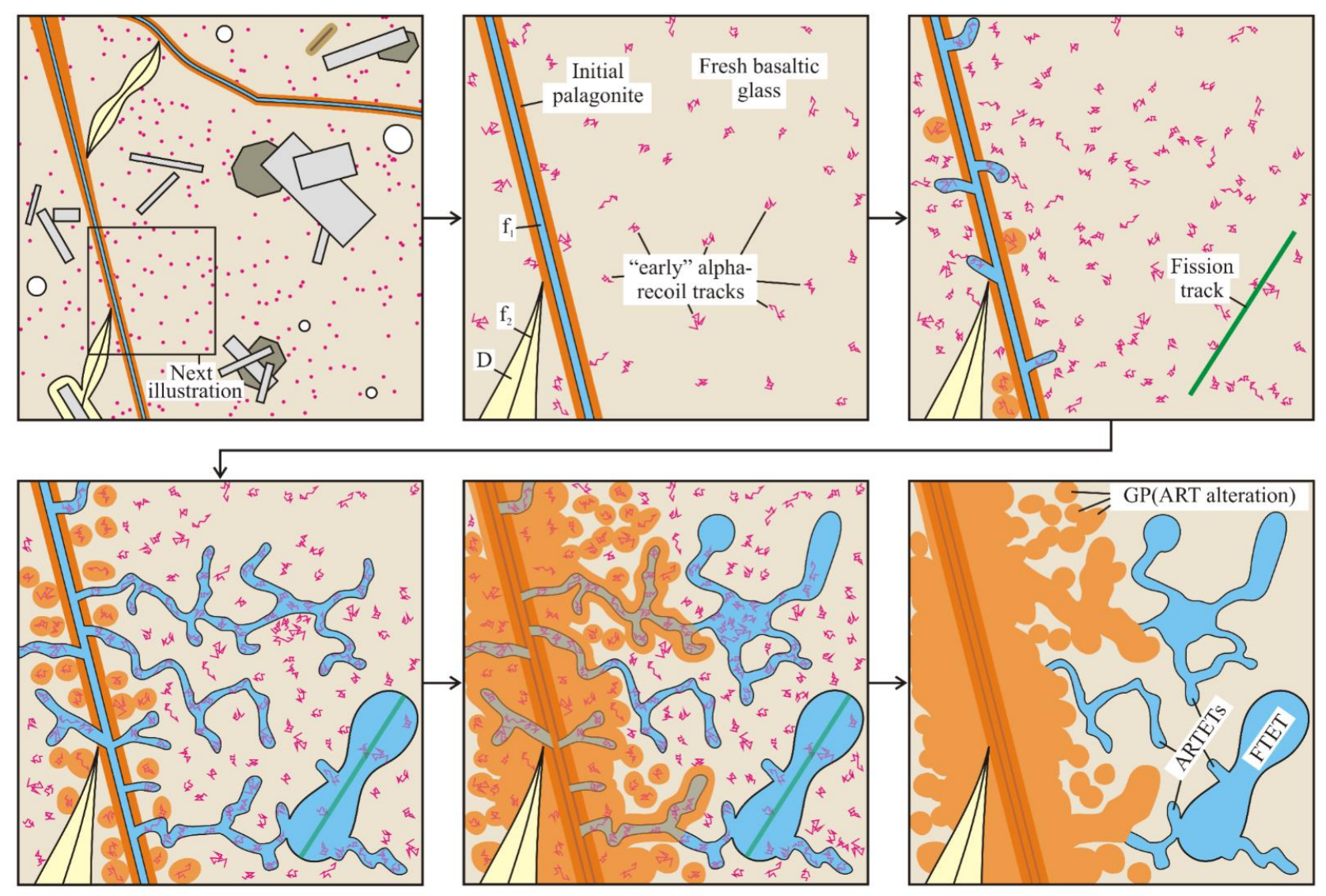

